\title{
LCA and communication: Environmental Product Declaration
}

\author{
Adriana Del Borghi
}

Received: 26 September 2012 / Accepted: 27 September 2012 / Published online: 10 October 2012

(C) The Author(s) 2012. This article is published with open access at Springerlink.com

Life cycle assessment (LCA) methodologies were originally developed to create decision support tools for distinguishing between products, product systems, or services on environmental grounds. During the evolution of the methodology, a number of related applications emerged, including its use as basis to communicate the overall environmental performance of the products to stakeholders.

Specific standards are available for LCA-based environmental labels and declarations. The International Standards Organization (ISO) has classified the existing environmental labels into three typologies - types I, II, and III-and has specified the preferential principles and procedures for each one of them (ISO 14021, ISO 14024, and ISO 14025) (ISO 1999a, b, 2006a; UNOPS 2009). An Environmental Product Declaration (EPD), also referred to as type III environmental declaration, is a standardized (ISO 14025) and LCA-based tool to communicate the environmental performance of a product (Grahl and Schmincke 2007). There are a number of requirements for how the LCA should be performed to be used as basis for an EPD. They are concerned on detailed specifications on how to model the product system in the LCA, what to include, what data to use, which environmental indicators to report, etc. These requirements are developed for different product groups by the industry and are referred to as product category rules (PCRs). The aim of the PCRs is to achieve comparability in results between different producers of the same product. And as such, the PCRs are valuable and useful as basis for any type of LCA to be used in external communication of results.

In 2002, to stimulate demand for greener products through easily accessible, understandable, and credible

\footnotetext{
A. Del Borghi $(\bowtie)$

Department of Civil, Chemical and Environmental Engineering, University of Genoa,

Via all'Opera Pia 15,

16145 Genoa, Italy

e-mail: adry@unige.it
}

information, Directorate-General (DG) Environment commissioned a study on the subject of EPDs (European Commission 2002), with the aim to document and evaluate national and sectoral EPD schemes as well as compare them with each other and with the current state of standardization work at ISO level. In 2012, 10 years after this report, DG Environment published the draft of a harmonized methodology for the calculation of the environmental footprint of products (including carbon) (European Commission 2012). Nowadays, EPD is even more a tool to communicate credible information about the environmental performance of products, and program harmonization is still a key issue to be managed to broaden its application. In fact, the growing number of different EPD schemes with different requirements can lead to trade barriers on that market, which could be avoided by the development of general guidelines regarding scheme management and the application of LCA and through the mutual recognition among the different schemes. The guide published by the European Commission moves in this direction. Table 1 summarizes the main existing programs to register EPDs or to build PCRs.

As a significant step toward harmonization of the various EPD schemes, during the first EPD stakeholder conference of 15 May 2012 (http://www.environdec.com/en/The-EPDsystem/Events/Conference-May-15-2012/), the process of mutual recognition between the International EPD System and IBU was presented and restricted to EPD of construction products including furniture and textiles built into a building. The mutual recognition means that the EPDs of both programs are accepted mutually without further verification. Most of the program characteristics already showed the right level for mutual recognition due to common reference to ISO 14025 and related standards.

An important role in harmonization of EPDs programs is played by collaboration initiatives, such as GEDnet, the 
Table 1 Existing EPD schemes

\begin{tabular}{|c|c|c|}
\hline Area & Initiative & URL \\
\hline \multirow[t]{3}{*}{ Asia } & The Environment and Development Foundation (EDF)—EPD & www.edf.org.tw \\
\hline & $\begin{array}{l}\text { Japan Environmental Management Association for } \\
\text { Industry (JEMAI) - PCF }\end{array}$ & www.cfp-japan.jp \\
\hline & $\begin{array}{l}\text { Korean Environmental Industry \& Technology Institute } \\
\text { (KEITI) - EPD }\end{array}$ & www.keiti.re.kr \\
\hline \multirow[t]{5}{*}{ Europe } & The International EPD System-EPD & www.environdec.com \\
\hline & The Norwegian EPD Foundation-EPD & www.epd-norge.no \\
\hline & $\begin{array}{l}\text { French Agency on Environment and Energy Management } \\
\text { (ADEME)-Product Environmental Footprint }\end{array}$ & $\begin{array}{l}\text { www.developpement-durable.gouv.fr/ } \\
\text { Product-Environmental-Footprint.html }\end{array}$ \\
\hline & $\begin{array}{l}\text { BRE Global Environmental Profiles Scheme (EPD) for } \\
\text { construction products - EPD }\end{array}$ & www.bre.co.uk \\
\hline & German Institute of Construction and Environment (IBU) & www.bau-umwelt.de \\
\hline \multirow[t]{6}{*}{ North America } & FP Innovations - EPD Program on Wood Products & $\begin{array}{l}\text { www.forintek.ca/public/eng/E5-Pub_Software/5a. } \\
\text { fact_sheets.html }\end{array}$ \\
\hline & NSF National Center for Sustainability Standards_-EPD & $\begin{array}{l}\text { www.nsf.org/business/sustainability_ncss/index.asp? } \\
\text { program=SustainabilityNcs }\end{array}$ \\
\hline & $\begin{array}{l}\text { The Institute for Environmental Research \& Education- } \\
\text { Earthsure EPD }\end{array}$ & www.iere.org/earthsure.aspx \\
\hline & The Green Standard-EPD & www.thegreenstandard.org/ \\
\hline & The Sustainability Consortium & www.sustainabilityconsortium.org/ \\
\hline & UL Environment-EPD & $\begin{array}{l}\text { www.ul.com/global/eng/pages/offerings/businesses/ } \\
\text { environment/services/certification/epd/ }\end{array}$ \\
\hline
\end{tabular}

$P C F$ product carbon footprint

Global Environmental Declarations Network (www.gednet. org). Its purpose is to foster cooperation and encourage information exchange among its members and other parties operating or developing type III environmental declaration programs and to discuss key issues in developing such programs. GEDnet has recently developed a global searchable PCR registry to disseminate basic knowledge about PCRs and their contents and to obtain better traceability among existing PCRs and PCF/PCRs in order to avoid duplication of PCR development thus reducing costs. A global alignment of PCRs represents a basic challenge to the efforts of achieving comparability of product claims (Ingwersen and Stevenson 2012; Subramanian et al. 2012).

Considering specific branches, the construction sector already reached a satisfactory level of harmonization. Specific guidelines have been developed, such as ISO 21930 (ISO 2007) and EN 15804 (CEN 2012), providing the core set of product category rules for the Europe-wide generation of Environmental Product Declarations for construction products, PCR basic module for construction products and construction services (PCR 2012), and PCR for construction materials, such as cement (PCR 2010), including specific rules to obtain Sector EPD certification (Strazza et al. 2010). A suite of new European standards is being developed for assessing the sustainability of construction products and the built environment by the CEN Technical Committee for the sustainability of construction works (CEN TC 350). On this basis, the
ECO platform, a European platform for EPD programs in the construction sector, is established with the aim of a common implementation of EN 15804 with mutual recognition among the members. The ECO Platform aims to initiate the development of a uniform European core EPD.

We should also remember the role played by professional societies, such as the Society of Environmental Toxicology and Chemistry (SETAC) in standardization and in the developing of LCA and EPD (Klöpffer 2006; SETAC Europe LCA Steering Committee 2008). In fact, the 13th SETAC Europe LCA Case Study Symposium on Environmental Product Declarations with focus on the building and construction sector has been a huge success.

In conclusion, harmonization can be achieved by defining minimum requirements for all EPD schemes. They can include program-related, such as independent verification, interested party participation, additional non-LCA data, common procedures for PCR development, and method- and data-related requirements, such as LCA according to ISO $14040+14044$ (ISO 2006b, c), set of indicators (inventory and impacts), rules for calculating the set of indicators, and data requirements (e.g., specific/generic and time frame). Therefore, the development of EPDs can be stimulated via several initiatives, including improving the harmonization of EPD schemes, stimulating the supply side by improved access to good quality LCA data, and stimulating the demand side by strengthening the link between public procurement and EPDs. 
Open Access This article is distributed under the terms of the Creative Commons Attribution License which permits any use, distribution, and reproduction in any medium, provided the original author(s) and the source are credited.

\section{References}

CEN (2012) Sustainability of construction works - environmental product declarations - core rules for the product category of construction products. European Standard EN 15804. European Committee for Standardization

European Commission DG Environment (2002) Evaluation of Environmental Product Declaration Schemes. B4-3040/2001/326493/ MAR/A2. http://ec.europa.eu/environment/ipp/pdf/epdstudy.pdf. Accessed 26 September 2012

European Commission Joint Research Centre (2012) Product Environmental Footprint (PEF) Guide Ref. Ares(2012)873782-17/07/2012. http:// ec.europa.eu/environment/eussd/pdf/footprint/PEF\%20methodology \%20final\%20draft.pdf. Accessed 26 September 2012

Grahl B, Schmincke E (2007) The part of LCA in ISO type III environmental declarations. Int J Life Cycle Assess 12(1):38-45

Ingwersen WW, Stevenson MJ (2012) Can we compare the environmental performance of this product to that one? An update on the development of product category rules and future challenges toward alignment. J Clean Prod 24:102-108

ISO (1999a) Environmental labels and declarations - self-declared environmental claims (type II environmental labelling). European Standard EN ISO 14021. International Organization for Standardization

ISO (1999b) Environmental labels and declarations-type I environmental labelling-principles and procedures. European
Standard EN ISO 14024. International Organization for Standardization

ISO (2006a) Environmental labels and declarations-type III environmental declarations - principles and procedures. European Standard EN ISO 14025. International Organization for Standardization

ISO (2006b) Environmental management-life cycle assessmentprinciples and framework. European Standard EN ISO 14040. International Organization for Standardization

ISO (2006c) Environmental management-life cycle assessmentrequirements and guidelines. European Standard EN ISO 14044. International Organization for Standardization

ISO (2007) Sustainability in building construction-environmental declaration of building products. European Standard EN ISO 21930. International Organization for Standardization

Klöpffer W (2006) The role of SETAC in the development of LCA. Int J Life Cycle Assess 11(Suppl 1):116-122

PCR (2010) PCR 2010:09 cement (UN CPC 3744). The International EPD System

PCR (2012) PCR 2012:01 construction products and construction services. The International EPD System

SETAC Europe LCA Steering Committee (2008) Standardisation efforts to measure greenhouse gases and 'carbon footprinting' for products (editorial). Int J Life Cycle Assess 13(2):87-88

Strazza C, Del Borghi A, Blengini GA, Gallo M (2010) Definition of the methodology for a Sector EPD (Environmental Product Declaration): case study of the average Italian cement. Int J Life Cycle Assess 15:540-548

Subramanian V, Ingwersen W, Hensler C, Collie H (2012) Comparing product category rules from different programs: learned outcomes toward s global alignment. Int J Life Cycle Assess 17:892-903

UNOPS (2009) A guide to environmental labels for procurement practitioners of the United Nations system. http://www.ungm.org. Accessed 26 September 2012 